\title{
INTERVENSI TINJAUAN HIDUP UNTUK MENURUNKAN SIMTOM DEPRESI LANSIA PENYANDANG OSTEOARTHRITIS DI LUTUT YANG MEMPUNYAI PERAN SEBAGAI CAREGIVER
}

\author{
${ }^{1}$ Sabina Wulung Rarasati, ${ }^{2}$ Srisiuni Sugoto \\ Magister Psikologi Profesi, Fakultas Psikologi, Universitas Surabaya \\ E-mail: sabinawulungrarasati@gmail.com
}

\begin{abstract}
This study aims is to determine effect of life review intervention to reduce depression symptoms in people with osteoarthritis in knee who also hav e caregiver role. The method used in this study is mixed method with interview, observation, and questionnaire. This study is conducted on an elderly woman who has depression symptoms in the mild category, burden as a caregiver in mild to moderate stages, and showed more dominant negative affect. Life review intervention is carried out by reviewing every life events from life and taking different perspective from it. The results from intervention showed that the participant experienced decreases in depression symptoms, caregiver burden, and change to positive affect.
\end{abstract}

Keywords: depression symptom, caregiver burden, osteoarthritis, life review intervention

\begin{abstract}
Abstrak: Penelitian ini bertujuan untuk melihat efek intervensi tinjauan hidup untuk mengurangi simptom depresi pada penyandang osteoarthritis di lutut yang juga mempunyai peran sebagai caregiver. Penelitian ini menggunakan desain mixed method dengan wawancara, observasi, dan kuesioner. Partisipan adalah seorang perempuan lanjut usia yang mempunyai simtom depresi pada kategori ringan, beban sebagai caregiver pada tahapan ringan sampai sedang, dan afek negatif yang lebih dominan. Intervensi tinjauan hidup dilakukan dengan cara meninjau seluruh peristiwa di setiap tahapan perkembangan dan melihat kembali dari sudut pandang yang berbeda. Hasil intervensi menunjukkan bahwa partisipan mengalami penurunan simptom depresi, penurunan beban sebagai caregiver, dan perubahan afek menjadi dominan positif.
\end{abstract}

Kata kunci: simptom depresi, beban caregiver, osteoarthritis, intervensi tinjauan hidup

\section{PENDAHULUAN}

WHO (2015) memperkirakan bahwa proporsi jumlah lanjut usia di dunia antara tahun 2015 dan 2050 bertambah dari 12\% sampai dengan 22\%. Di Indonesia sendiri, dengan penambahan jumlah lanjut usia dari 18 juta di tahun 2010, menjadi 25,9 juta jiwa di tahun 2019, diestimasikan bertambah di tahun 2035 menjadi 48,2 juta jiwa (Kemenkes RI, 2019). Dari data tersebut, dapat dikatakan jika angka harapan hidup dan pertumbuhan jumlah lansia di Indonesia akan semakin meningkat. Di sisi lain, lansia merupakan populasi yang rentan mengalami depresi (Luppa, 2012). Dengan adanya peningkatan jumlah penduduk lansia, maka kemungkinan lansia yang mengalami depresi akan semakin bertambah.

Secara umum, menurut DSM-V, depresi memiliki arti umum, seperti perasaan kesedihan, hampa, atau mudah tersinggung, yang bersama dengan adanya distorsi pikiran dan gejala somatik tertentu sehingga menyebabkan gangguan atau penurunan fungsi yang signifikan (APA, 2013). Simtom depresi 
umum pada usia lanjut dan terjadi pada kisaran ringan sampai berat (Glaesmer et al., 2011).

Banyak yang menjadi penyebab depresi pada lansia seperti keadaan menjanda atau hanya tinggal seorang diri, mempunyai kesehatan yang buruk atau penyakit kronis, kemunduran kemampuan kognitif atau demensia, tekanan finansial atau kemiskinan, perbedaaan gender sebagaimana perempuan memiliki tingkat kerentanan lebih tinggi dibandingkan laki-laki, dan tugas sebagai caregiver (Girgus, Yang, Ferri, 2017). Begitu pula dengan partisipan dalam penelitian ini yang mengalami simtom depresi ringan karena mempunyai permasalahan ganda sebagai caregiver dan penyandang osteoarthritis tingkat II di lutut sebagai penyakit yang kerap muncul di usia lanjut.

Peran caregiver sendiri di beberapa konteks budaya, seperti di dalam budaya Jawa sering diidentikan sebagai tugas seorang perempuan. Survei kepada perempuan Jawa ( $\mathrm{T}=94)$ yang memaknai perannya adalah mengurus anak-anak 70,2\%, mengurus suami $66,0 \%$, mengatur rumah tangga $37 \%$, dan tidak lupa dengan kodrat sebagai perempuan sebanyak 56,4\% (Permanadeli, 2015). Hasil yang didapatkan merupakan perwujudan dari internalisasi budaya Jawa yang cenderung lebih mendidik perempuan untuk mengatasi persoalan praktis di rumah (Handayani \& Novianto, 2004). Begitu pula dengan partisipan penelitian ini yang mempunyai latar belakang budaya Jawa yang pada masa remaja disarankan oleh ibunya untuk lebih baik menikah saja dan berperan di ranah domestik saja daripada melanjutkan pendidikan atau berkarier.

Menjadi seorang caregiver atau mempunyai peran sebagai caregiver dapat menimbulkan adanya beban caregiver. Beban caregiver sendiri sering menjadi penyebab adanya simtom depresi. Meta-analisis yang dilakukan oleh (del-Pino-Casado et al, 2019) menemukan bahwa mengalami beban caregiver dikaitkan dengan peningkatan resiko depresi tingkat sedang dan sumber yang signifikan dari adanya simtom depresi.

Selain tugas atau peran sebagai caregiver, penyakit juga dapat menjadi penyebab munculnya simtom depresi pada seseorang, misalnya adanya nyeri pada penyakit osteoarthritis di lutut yang merupakan suatu penyakit tulang rawan yang mengalami kerusakan, penipisan dan akhirnya hilang sama sekali (Kisworo, 2017). Penelitian yang dilakukan oleh (Zheng et al., 2021) menemukan depresi banyak terjadi pada populasi penyandang osteoarthritis di lutut dengan prevalensi $25,4 \%$ dan kejadian $11,2 \%$ selama 24 bulan. Selain itu pasien osteoarthritis di lutut yang berjenis kelamin perempuan banyak diasosiasikan dengan depresi.

Simtom depresi perlu untuk ditangani karena depresi di taraf ringan sampai sedang dapat mengakibatkan adanya gangguan tidur seperti insomnia (Taylor et al., 2007). Jika depresi berlanjut sampai ke tingkat yang lebih parah, bahkan dapat menjadi prediktor kasus 
bunuh diri di segala usia, termasuk pada lansia (Rossom et al., 2019).

Untuk menurunkan simtom depresi, banyak yang dapat dilakukan yaitu dengan metode farmakoterapi, psikoterapi, atau menggunakan gabungan kedua cara tersebut. Bukti menunjukkan bahwa psikoterapi maupun farmakoterapi sama efektifnya dalam jangka pendek, tetapi psikoterapi lebih baik dalam jangka panjang (Leichsenrig, Steinert, Hoyer, 2016). Sehingga dapat ditarik kesimpulan jika psikoterapi berperan penting untuk menurukan simtom depresi baik penggunaan tunggal maupun gabungan supaya hasil lebih efektif untuk menurunkan simtom depresi.

Psikoterapi yang terbukti efektif untuk mengatasi depresi pada lansia antara lain adalah CBT dan problem solving therapy (Cujipers et al, 2014). Selain itu, intervensi tinjauan hidup juga terbukti dapat mengatasi depresi pada lansia. Intervensi ini merupakan teknik intervensi yang pertama kali dikembangkan untuk menangani masalah psikologis pada lanjut usia, serta dapat dianggap sebagai metode pengobatan khusus yang mana partisipan diminta untuk melaporkan ingatan mereka secara rinci, terstruktur, dan sesuai dengan fase kehidupan, misalnya masa kanak-kanak, remaja, muda, menengah, dan dewasa tua dan menunjukkan keefektifannya untuk mengatasi simptom depresi (Haight \& Haight dalam Maercker \& Bachem, 2013; Maercker \& Bachem, 2013). Oleh karena itu, peneliti memilih intervensi tinjauan hidup untuk menurunkan simtom depresi karena dari survei awal, peneliti sudah melihat bahwa partisipan mempunyai daya tanggap yang baik dan penyeselan yang belum selesai di fase kehidupan lain, sehingga peneliti merasa bahwa partisipan dapat mengikuti proses intervensi tinjauan hidup yang mencakup proses pengambilan makna dari pengalaman hidup di setiap tahapan perkembangan.

Beberapa penelitian tentang pengaruh tinjauan hidup untuk mengurangi depresi pada lansia menunjukkan penurunan yang signifikan untuk menurunkan tingkat depresi, mengurangi, kecemasan, serta memperkuat kesehatan mental yang lebih positif (Gonçalves, Albuquerque, Paul 2009; Pot, 2010; Korte et al., 2012). Metaanalisis yang dilakukan oleh (Westerhof \& Slatman, 2019) menemukan efek yang signifikan dalam mengurangi simtom-simtom depresi pada post-treatment.

Penelitian ini bertujuan untuk melihat efek intervensi tinjauan hidup untuk mengatasi simtom depresi pada lansia. Sebagai kebaruan penelitian beberapa penelitian tentang lansia sebagian besar dilakukan pada lansia yang bertempat tinggal di mental-health service, adult social centre, mental health organization (Gonçalves, 2009; Pot, 2010; Korte, 2012;) dan jarang yang menjelaskan bagaimana lansia yang bertempat tinggal di rumah sendiri dan mempunyai tugas sebagai caregiver di dalam konteks budaya Jawa. Di dalam penelitian ini, juga dilakukan asesmen terlebih dahulu terhadapan partisipan dan menggabungkan teknik psikoedukasi sebagai tambahan. 


\section{METODE}

\section{Rancangan Penelitian}

Penelitian ini menggunakan gabungan kualitatif dan kuantitatif, yaitu mixed method dengan pendekatan intervensi berbasis psikososial Erik Erikson dalam yaitu dengan menggunakan intervensi tinjauan hidup. Selain itu, penelitian ini juga menggunakan psikoedukasi dengan cara merancang modul sebagai bahan pendampingan bagi partisipan. Untuk mengevaluasi hasil dari suatu perlakuan, peneliti membandingkan pengukuran sebelum dan sesudah perlakuan dan melihat perubahan secara kuantiatif dan kualitatif.

\section{Partisipan Penelitian}

Partisipan adalah seorang janda perempuan berumur 67 tahun yang hanya tinggal berdua dengan ibunya. Partisipan mengalami simtom-simtom depresi seperti kesulitan untuk tidur di malam hari dan sering menangis tiba-tiba. Simtom depresi tersebut berasal dari tugas caregiver almarhum suaminya yang menderita Parkinson selama empat tahun dan ibunya yang menderita Hipertensi selama tujuh tahun. Hal tersebut diperparah dengan adanya penyakit osteoarthritis stadium II di bagian lututnya sehingga tidak bebas beraktivitas padahal partisipan adalah seseorang yang mempunyai tuntutan tinggi terhadap dirinya dalam lingkungan pergaulan dan tugas rumah tangga. Di sisi lain, partisipan memiliki beberapa pengalaman yang masih menjadi penyesalan di dalam hidupnya seperti menikah cepat di masa remaja, keinginan melanjutkan sekolah dan berkarier sebagai perawat yang tidak terpenuhi.

\section{Pengumpulan Data}

Pada penelitian ini, data diperoleh dengan observasi dan wawancara. Selain itu, dengan pengisian skala Beck Depression IndexII (BDI-II) untuk mendiagnosis gangguan depresi yang mencakup item yang mengukur gejala depresi kognitif, afektif, dan vegetatif, Zarith Burden Interview (ZBI) untuk beban caregiver yang terdiri dari 22 item yang dinilai pada skala likert, 20 item ukuran laporan diri dari skala Positive Affect Negative Affect Scale (PANAS) yang dikembangkan oleh Watson, Clark, dan Tellegen (1988b dalam Watson \& Clark, 1999; Al-Rawashdeh, 2009; Smarr \& Keefer, 2011).

\section{Analisis Data}

Analisis data dilakukan dengan dua cara yaitu kualitatif yang dilakukan dengan menggunakan analisis isi kualitatif (AIK) dari hasil wawancara dan observasi serta kuantitatif dengan melihat pre-test dan post test BDI-II, ZBI, maupun PANAS.

\section{HASIL}

Dari observasi dan wawancara menunjukkan terjadinya penurunan simtom depresi pada diri partisipan. Melalui tinjauan kehidupan pula, partisipan dapat mengambil sudut pandang lain terhadap kewajibannya untuk melakukan tugas sebagai caregiver, mengurangi tuntutan-tuntutan yang ada di dalam dirinya, kekecewaan dirinya dahulu yang menikah di usia remaja sehingga dirinya tidak 
bisa melanjutkan sekolah sehingga gagal memenuhi cita-citanya menjadi seorang perawat atau menjadi wanita karier, dan dapat lebih menerima bahwa dirinya mengalami penyakit osteoarthritis tingkat II di lutut.

Tabel 1. Hasil Observasi dan Wawancara

\begin{tabular}{|c|c|c|}
\hline Simtom & $\begin{array}{l}\text { Sebelum } \\
\text { Intervensi }\end{array}$ & $\begin{array}{l}\text { Setelah } \\
\text { Intervensi }\end{array}$ \\
\hline Somatik & $\begin{array}{l}\text { Partisipan } \\
\text { seringkali } \\
\text { kesulitan tidur di } \\
\text { malam hari }\end{array}$ & $\begin{array}{l}\text { Sudah dapat tidur } \\
\text { lebih nyenyak } \\
\text { setelah intervensi }\end{array}$ \\
\hline $\begin{array}{l}\text { Kognitif- } \\
\text { Afektif }\end{array}$ & $\begin{array}{l}\text { Partisipan } \\
\text { merasa minder } \\
\text { karena dirinya } \\
\text { tidak melanjutkan } \\
\text { sekolah dan } \\
\text { mempunyai } \\
\text { karier seperti } \\
\text { teman-temannya }\end{array}$ & $\begin{array}{l}\text { Sudah dapat lebih } \\
\text { menerima bahwa } \\
\text { dirinya bisa } \\
\text { membesarkan } \\
\text { anak-anaknya } \\
\text { dengan baik, serta } \\
\text { mempunyai suami } \\
\text { yang baik }\end{array}$ \\
\hline
\end{tabular}

\begin{tabular}{|c|c|}
\hline $\begin{array}{lr}\text { Merasa } & \text { terbebani } \\
\text { dan } & \text { khawatir } \\
\text { dengan } & \text { tugas } \\
\text { sebagai } & \text { caregiver }\end{array}$ & $\begin{array}{lr}\text { Dapat } & \text { melihat } \\
\text { tugas } & \text { sebagai } \\
\text { sebagai } & \text { suatu } \\
\text { kebanggaan } & \end{array}$ \\
\hline $\begin{array}{l}\text { Partisipan sering } \\
\text { menangis } \\
\text { tiba }\end{array}$ & $\begin{array}{l}\text { Partisipan lebih } \\
\text { jarang menangis }\end{array}$ \\
\hline $\begin{array}{l}\text { Partisipan sering } \\
\text { memaksakan diri } \\
\text { mengerjakan } \\
\text { pekerjaan rumah } \\
\text { tangga yang } \\
\text { membuat kakinya } \\
\text { sakit }\end{array}$ & $\begin{array}{l}\text { Partisipan lebih } \\
\text { santai dalam } \\
\text { mengerjakan } \\
\text { pekerjaan rumah } \\
\text { tangga sehingga }\end{array}$ \\
\hline $\begin{array}{l}\text { Partisipan kurang } \\
\text { bisa menerima } \\
\text { sepenuhnya } \\
\text { mengapa dari } \\
\text { sekian banyak } \\
\text { orang dirinya } \\
\text { yang terkena } \\
\text { penyakit } \\
\text { osteoarthritis }\end{array}$ & $\begin{array}{l}\text { Partisipan lebih } \\
\text { memhami dan } \\
\text { lebih menerima } \\
\text { bahwa dirinya } \\
\text { sudah mengalami } \\
\text { kemunduran fisik, } \\
\text { sehingga adanya } \\
\text { penyakit seperti } \\
\text { osteoarthritis II di } \\
\text { lutut merupakan }\end{array}$ \\
\hline
\end{tabular}

tingkat II di lutut. hal yang wajar

Selain hasil kualitatif, peneliti juga melihat hasil kuantitatif dan menemukan bahwa terdapat perubahan tingkat depresi, beban caregiver, dan peningkatan afek menjadi lebih positif pada diri partisipan. Perubahan ini tampak pada hasil pengukuran BDI-II, ZBI, dan PANAS, dimana partisipan mengalami penurunan tingkat depresi, beban sebagai caregiver, dan perubahan afek menjadi lebih positif.

Tabel 2. Hasil Pengukuran BDI-II

\begin{tabular}{lll}
\hline & Pre-test & Post-test \\
\hline Skor BDI-II & 18 & 8 \\
\hline Kategori & $\begin{array}{l}\text { Depresi } \\
\text { Ringan }\end{array}$ & Normal \\
\hline
\end{tabular}

Tabel 3. Hasil Pengukuran ZBI

\begin{tabular}{lll}
\hline & Pre-test & Post-test \\
\hline Skor ZBI & 35 & 28 \\
\hline Kategori & Ada beban & Ada \\
& ringan & beban \\
& sampai & ringan \\
& sedang & sampai \\
& & ringan \\
\hline
\end{tabular}

Tabel 4. Hasil Pengukuran PANAS

\begin{tabular}{|c|c|c|}
\hline & Pre-test & Post-test \\
\hline \multirow{5}{*}{$\begin{array}{l}\text { Skor } \\
\text { PANAS }\end{array}$} & \multicolumn{2}{|l|}{ mendapatkan } \\
\hline & negatif & afek negatif \\
\hline & sebesar & sebesar $\quad 29$ \\
\hline & dan afek & dan afek \\
\hline & $\begin{array}{l}\text { positif sebear } \\
25\end{array}$ & $\begin{array}{l}\text { positif } \\
\text { sebear } 34\end{array}$ \\
\hline
\end{tabular}

Berdasarkan tabel hasil pengukuran BDI-II pada pengukuran pre-test didapatkan skor sebesar 18 yang masuk pada kategori depresi ringan sedangkan pada post test didapatkan 
skor sebesar 8 yang masuk pada kategori normal atau tidak depresi. Sehingga dapat dikatakan terjadi penurunan tingkat depresi sebesar 10 poin.

Selanjutnya, hasil pengukuran beban sebagai caregiver didapatkan skor sebesar 35 dalam pengukuran pre-test yang masuk kategori beban ringan sampai dengan sedang dan mendapat skor sebanyak 28 pada saat post test yang masih masuk pada kategori beban ringan sampai sedang. Walaupun masih masuk pada kategori beban ringan sampai dengan sedang tetapi tetapi terjadi penurunan tingkat beban sebagai caregiver sebanyak 7 poin.

Untuk perubahan afek, dengan melihat tabel PANAS, pada saat pre-test didapatkan skor afek negatif sebesar 29 dan afek positif sebesar 25, sedangkan pada saat post-test didapatkan skor afek negatif sebesar 29 dan afek positif sebesar 34.

\section{PEMBAHASAN}

Dalam penelitian ini, partisipan dapat memaknai dan memandang hidup keseluruhan dari sudut pandang lain sehingga merasa lebih bersyukur dan memandang kehidupan keseluruhan secara lebih positif. Hal tersebut ditandai dengan penurunan tingkat simtom depresi sampai dengan 10 poin sehingga dapat dikatakan ada penurunan skor depresi dari pretest yang termasuk kategori ringan dan post-test yang masuk kategori normal atau tidak depresi. Selain penurunan skor depresi, partisipan juga mengalami penurunan skor dalam hal beban caregiver walaupun menurut ZBI penurunan skor beban caregiver tidak mengganti kategori di dalam pre test yang masuk dalam kategori beban ringan sampai sedang, akan tetapi secara kuantitatif dapat berkurang sampai dengan 8 poin, sehingga intervensi tinjauan hidup cukup efektif untuk mengatasi depresi dan afek negatif yang dalam penelitian ini diukur melalui skala PANAS.

Partisipan dalam penelitian ini memiliki simtom depresi. Depresi sendiri dalam konsep psikososial Erikson adalah keadaan despair yang berlawanan dengan pemenuhan ego-integrity di masa lansia (Haber, 2006). Hal ini tampak dari data wawancara yang menjelaskan bahwa partisipan mempunyai gangguan tidur di malam hari dan seringkali menangis tiba-tiba. Simtom-simtom depresi tersebut berasal dari beban sebagai caregiver, sakit osteoarthritis tingkat II di lutut, serta adanya penyesalan yang belum selesai di tahapan kehidupans sebelumnya yang membebani pikiran partisipan.

Partisipan juga diminta ibunya supaya dirinya saja yang melakukan tugas merawat ibunya. Jika ditilik dari pandangan budaya hal ini terkait dengan konsep-konsep kehidupan bermasyarakat Jawa, seperti orang tua lebih memilih anak perempuan daripada laki-laki untuk merawatnya (ngrumat)karena dipandang lebih dapat diandalkan (Handayani \& Novianto, 2004).

Peneliti memberikan intervensi tinjauan hidup terhadap partisipan untuk menurunkan simtom depresi. Hasil penelitian menunjukkan bahwa partisipan mengalami 
penurunan simtom depresi, yaitu dari depresi ringan menjadi normal atau tidak depresi. Hal ini sebanding dengan temuan (Gonçalves, Albuquerque, Paul 2009; Pot, 2010; Korte et al., 2012) bahwa tinjauan hidup efektif untuk mengurangi depresi pada lansia.

Selain simtom depresi, beban caregiver yang dialami partisipan juga mengalami penurunan. Hal ini dapat dipahami karena depresi dan beban caregiver terkait satu sama lain. Menurut penelitian (Kršíková \& Zeleníková, 2018), ada korelasi positif antara depresi yang diukur dengan Beck Depression Inventory dan kedua skor Zarit Burden Interview (0,4898). Hasil penelitian pilot mengkonfirmasi bahwa seorang caregiver beresiko mengalami depresi terkait dengan beban perawatan pasien demensia.

Selain simtom depresi dan beban caregiver, juga terdapat peningkatan afek yang sebelumnya lebih didominasi dengan afek negatif setelah intervensi menjadi afek positif berdasarkan skala PANAS. Hal ini sesuai oleh penelitian (Wang et al, 2017) menggunakan analisis regresi untuk menganalisis dan mengklarifikasi hubungan antara NA, PA rendah, dan fungsi eksekutif, dan depresi pada kelompok paruh baya dan lansia. Skor depresi dijelaskan melalui NA dan PA yang rendah, yang terhitung $24 \%$ dari variansi dalam kelompok paruh baya, dimana skor depresi dijelaskan dengan NA dan PA rendah, yang terhitung sebanyak $34 \quad \% \quad$ dari variansi kelompok lansia.
Peneliti melakukan tinjauan kehidupan dari masa remaja karena partisipan dalam penelitian ini mulai memiliki masalah dalam tahapan perkembangan ketika remaja, yaitu ketika ia menikah di masa remaja. Menurut Erik Erikson (dalam Santrock, 2011) remaja menghadapi tahapan perkembngan identity vs identity confusion dimana remaja menghadapi siapa mereka, tentang apa mereka dan apa yang akan mereka lakukan di kehidupan mereka. Partisipan juga diminta menuliskannya di dalam lembar intervensi yang ada di dalam modul psikoedukasi dan membantunya untuk melihat sudut pandang lain dibalik peristiwa yang dianggap negatif dengan menggunakan teknik-teknik konseling seperti teknik reframing maupun challenging. Meskipun ulasan hidup mungkin hanya pengalaman lisan, versi tertulis tambahan kemungkinan akan menambah potensinya untuk berdampak pada kesehatan mental (Sherman, 1991, 1995a dalam Haber 2006). Dapat pula dengan menggunakan wawancara yang direkam dengan tape recorder atau dengan catatan tertulis (Haber, 2006).

\section{SIMPULAN}

Hasil penelitian menunjukkan bahwa intervensi tinjauan hidup mampu menurunkan simtom depresi yang akhirnya berpengaruh pada penurunan beban caregiver dan peningkatan afek positif pada lansia sehingga dapat mendukung untuk mencapai integritas ego di masa lansia.

Penelitian ini terbatas pada partisipan tunggal sehingga tidak dapat ditarik kesimpulan 
secara umum. Untuk penelitian selanjutnya dapat melibatkan partisipan yang lebih banyak dengan variasi tingkat depresi yang berbeda dan konteks budaya, serta latar belakang yang berbeda pula supaya hasil penelitian yang dihasilkan juga semakin kaya.

\section{DAFTAR RUJUKAN}

Al-Rawashdeh, S. Y., Lennie, T. A., \& Chung, M. L. (2016). Psychometrics of the Zarit Burden Interview in caregivers of patients with heart failure. The Journal of cardiovascular nursing, 31(6), E21.

American Psychiatric Association (2013). Diagnostic and Statistical Manual of Mental Disorder Fifth Edition (DSMV). Washington : American Psychiatric Publishing

Cuijpers, P., Karyotaki, E., Pot, A. M., Park, M., \& Reynolds III, C. F. (2014). Managing depression in older age: psychological interventions. Maturitas, 79(2), 160169.

del-Pino-Casado, R., Rodriguez Cardosa, M., López-Martínez, C., \& Orgeta, V. (2019). The association between subjective caregiver burden and depressive symptoms in carers of older relatives: A systematic review and meta-analysis. PloS one, 14(5), e0217648.

Girgus, J. S., Yang, K., \& Ferri, C. V. (2017). The gender difference in depression: are elderly women at greater risk for depression than elderly men?. Geriatrics, 2(4), 35.

Glaesmer, H., Riedel-Heller, S., Braehler, E., Spangenberg, L., \& Luppa, M. (2011). Age-and gender-specific prevalence and risk factors for depressive symptoms in the elderly: a populationbased study. International psycho geriatrics, 23(8), 1294.
Gonçalves, D. C., C. (2009). Life review with older women: an intervention to reduce depression and improve autobiographical memory. Aging clinical and experimental research, 21(4), 369-371.

Haber, D. (2006). Life review: Implementation, theory, research, and therapy. The International Journal of Aging and Human Development, 63(2), 153-171.

Handayani, C.S \& Novianto, A (2004). Kuasa wanita jawa. Yogyakarta: Lkis

Kemenkes, 2019. Indonesia Masuki Periode Aging Population. kemkes.go.id. Diunduh dari https://www.kemkes.go.id/article/view/ 19070500004/indonesia-masukiperiode-aging-population.html

Kisworo, Bambang (2017). Osteoartritis \& Operasi Penggantian Sendi Lutut Panggul. Edisi 3. Rumah Sakit Panti Rapih : Yogyakarta

Korte, J., Bohlmeijer, E. T., Cappeliez, P., Smit, F., \& Westerhof, G. J. (2012). Life review therapy for older adults with moderate depressive symptomatology: A pragmatic randomized controlled trial. Psychological medicine, 42(6), 1163.

Kršíková, T., \& Zeleníková, R. (2018). Association between burden and depression in caregivers of dementia patients. Central European Journal of Nursing and Midwifery, 9(3), 866.

Leichsenring, F., Steinert, C., \& Hoyer, J. (2016). Psychotherapy versus pharmacotherapy of depression: What's the evidence?. Zeitschrift für Psychosomatische Medizin und Psychotherapie, 62(2), 190-195.

Luppa, M., Sikorski, C., Luck, T., Ehreke, L., Konnopka, A., Wiese, B., ... \& RiedelHeller, S. G. (2012). Age-and genderspecific prevalence of depression in 
latest-life-systematic review and me ta-n analysis. Journal of affective disorders, 136(3), 212-221.

Maercker, A., \& Bachem, R. (2013). Lifereview interventions as psychotherapeutic techniques in psychotraumatology. European Journal of Psychotraumatology, 4(1), 19720.

Permanadeli, Risa (2015). Dadi wong wadon: Representasi sosial perempuan Jawa di Era Modern. Pustaka Ifada: Yogyakarta.

Pot, A. M., Bohlmeijer, E. T., Onrust, S., Melenhorst, A. S., Veerbeek, M., \& De Vries, W. (2010). The impact of life review on depression in older adults: a randomized controlled trial. International

Psychogeriatrics, 22(4), 572.

Rossom, R. C., Simon, G. E., Coleman, K. J., Beck, A., Oliver, M., Stewart, C., \& Ahmedani, B. (2019). Are wishes for death or suicidal ideation symptoms of depression in older adults?. Aging \& mental health, 23(7), 912-918.

Santrock, John W (2011). Life Span Development. Thirteenth Edition. New York : McGraw-Hill

Smarr, KL, \& Keefer, AL (2011). Measures of depression and depressive symptoms: beck depression inventory $\square$ II (BDI $\square$ II), Center for Epidemiologic Studies Depression Scale (CES $\square \mathrm{D})$, geriatric depression scale (GDS), hospital anxiety and depression scale (HADS), and patient health Questionnaire $\square 9$ (PHQ $\square$ 9). Arthritis care \& research, 63 (S11), S454-S466.

Taylor, D. J., Lichstein, K. L., Weinstock, J., Sanford, S., \& Temple, J. R. (2007). A pilot study of cognitive-behavioral therapy of insomnia in people with mild depression. Behavior Therapy, 38(1), 49-57.
Wang, K. C., Yip, P. K., Lu, Y. Y., \& Yeh, Z. T. (2017). Depression in older adults among community: the role of executive function. International Journal of Gerontology, 11(4), 230234.

Watson, D., \& Clark, L. A. (1999). The PANAS-X: Manual for the positive and negative affect schedule-expanded form.

Westerhof, G. J., \& Slatman, S. (2019). In search of the best evidence for life review therapy to reduce depressive symptoms in older adults: A metaanalysis of randomized controlled trials. Clinical Psychology: Science and Practice, 26(4), e12301.

World Health Organization (2017). www.who.int. Diunduh dari https://www.who.int/news-room/factsheets/detail/ageing-and-health

Zheng, S., Tu, L., Cicuttini, F., Zhu, Z., Han, W., Antony, B., ... \& Ding, C. (2021). Depression in patients with knee osteoarthritis: risk factors and associations with joint symptoms. $B M C$ musculoskeletal disorders, 22(1), 1-10. 